\title{
[5्चSPCR
}

\section{Study of Antibiotic Use on Pneumonia Patient in Surakarta Referral Hospital}

\section{Studi Penggunaan Antibiotik Pada Pasien Pneumonia di Rumah Sakit Rujukan Daerah Surakarta}

\author{
Yeni Farida $^{1 *}$, Ayu Trisna ${ }^{2}$, Deasy Nur $\mathbf{W}^{2}$ \\ 1 Jurusan Farmasi Fakultas Matematika dan Ilmu Pengetahuan Alam Universitas Sebelas Maret \\ Surakarta \\ ${ }^{2}$ Prodi D3 Farmasi Fakultas Matematika dan Ilmu Pengetahuan Alam Universitas Sebelas Maret \\ Surakarta \\ *email korespondensi: yenifarida @ staff.uns.ac.id
}

\begin{abstract}
Pneumonia is lung inflammation, mostly caused by bacteria. Antibiotics are the primary therapy in cases of pneumonia due to bacteria. This study aimed to determine the profiles of pneumonia patients and their use of antibioticsin Surakarta referral hospital.Data were collected retrospectively by using patient's medical recordand prescription on 2014-2015. Subject were obtained by purposive sampling. Patients diagnosed pneumonia with antibiotik therapywere included while patient with comorbide other infection were excluded. The result showed that the most pneumonia patient were aged $0-5$ years old $(27,71 \%$, female and the average length of stay 11 days) The most single use antibiotik in pediatric patients and adults was ceftriaxone $(21.09 \%$ and $66.12 \%$ respectively). The combination of antibiotics that were widely used in pediatric patients were ampicillin-gentamicin (39.27\%), while in adult patients were ceftriaxone and azithromycin $(26.97 \%)$.
\end{abstract}

\section{Keywords: pneumonia, patient profiles, antibiotics}

Pneumonia merupakan peradangan paru yang sebagian besar disebabkan oleh bakteri. Terapi utama pneumonia dengan penyebab bakteri adalah antibiotik. Penelitian ini bertujuan untuk mengetahui profil pasien dan pola penggunaan antibiotik pada pneumonia rawat inap di daerah Surakarta. Data diperoleh secara retrospektif dari rekam medis dan lembar reseppada tahun 2014-2015. Subyek penelitian diperoleh dengan purposive sampling dengan kriteria inklusi pasien pneumonia yang mendapatkan antibiotik dan kriteria eksklusinya adalah pasien dengan penyakit penyerta infeksi lain. Hasil penelitian menunjukan bahwa sebagian besar penderita pneumonia adalah pasien usia 0-5 tahun $(27,71 \%)$ berjenis kelamin perempuan dengan lama perawatan rata-rata 11 hari. Antibiotik 
tunggal yang banyak digunakan pada pasien anak maupun dewasa adalah seftriakson $(21,09 \%$ dan 66,12\%).. Kombinasi antibiotik yang banyak digunakan pada pasien anak adalah ampisilin-gentamisin $(39,27 \%)$ sedangkan pada pasien dewasa adalah seftriakson dan azitromisin $(26,97 \%)$.

Kata kunci : pneumonia, profil pasien, antibiotik

\section{Pendahuluan}

Dari data Riskesdas (2013) terjadi peningkatan prevalensi pneumonia pada semua umur dari 2,1\% (2007) menjadi 2,7\% (2013). Berdasarkan kelompok umur penduduk, prevalensi pneumonia yang tinggi terjadi pada 2 kelompok umur 1-4 tahun, kemudian mulai meningkat pada umur 45-54 tahun dan terus meningkat pada kelompok umur berikutnya. Pneumonia merupakan penyebab kematian terbesar pada anak di seluruh dunia. Pada tahun 2015, terjadi 920.136 kematian akibat pneumonia, 16\% dari seluruh kematian anak usia kurang dari 5 tahun (WHO, 2016).

Pneumonia adalah peradangan paru yang menyebabkan nyeri saat bernafas dan keterbatasan intake oksigen. Pneumonia dapat disebarkan dengan berbagai cara antara lain pada saat batuk dan bersin (WHO, 2014). Pneumonia dapat disebabkan oleh bakteri, virus, dan jamur. Sebagian besar disebabkan oleh bakteri. Bakteri penyebab pneumonia dibagi menjadi organisme gram positif atau gram negatif seperti : Streptococcus pneumoniae (pneumococus), Staphylococcus aureus, Enterococcus, Streptococus piogenes, Pseudomonas aeruginosa, Klebsiella pneumoniae, dan Haemophillus influenzae. Pneumonia yang disebabkan oleh jamur jarang terjadi, tetapi hal ini mungin terjadi pada individu dengan masalah sistem imun yang disebabkan AIDS, obat obatan imunosupresif atau masalah kesehatan lain. Patofisiologi dari pneumonia oleh jamur mirip dengan pneumonia yang disebabkan oleh bakteri. Pneumonia yang disebabkan jamur paling sering disebabkan oleh Histoplasma capsulatum, Cryptococcus neoformas, Candida sp., Aspergillus sp., Pneumocystis jiroveci dan Coccidioides immitis (Khairudin, 2009). Virus yang tersering menyebabkan pneumonia adalah Respiratory Syncial Virus (RSV). Meskipun virusvirus ini kebanyakan menyerang saluran pernapasan bagian atas, pada balita gangguan ini bisa memicu pneumonia (Misnadiarly, 2008).

Antibiotik merupakan terapi utama pneumonia yang disebabkan bakteri. Antibiotik yang disarankan sebagai terapi empirik pneumonia rawat inap antara lain sefalosporin generasi ketiga dikombinasikan dengan makrolida, florokuinolon monoterapi dan tigesiklin untuk pasien yang intoleran sefalosopin dan florokuinolon (File et.al, 2016). Pemilihan penggunaan antibiotik pada pasien bersifat individual baik dengan pengobatan tunggal maupun dengan pengobatan kombinasi. Penelitian ini dilakukan untuk melihat karakteristik pasien pneumonia dan penggunaan antibiotiknya pada tahun 2014 dan 2015.

\section{Metode Penelitian}

Penelitian yang dilakukan merupakan penelitian deskriptif non eksperimental. Pengambilan data dilakukan secara retrospektif dengan mengambil data pada rekam medis pasien dan resep di 
instalasi farmasi. Penelitian dilakukan dengan menganalisis profil pasien dan pemberian terapi antibiotik pada pasien pneumonia.

\subsection{Subyek Penelitian}

Populasi penelitian adalah semua pasien yang didiagnosis pneumonia yang menjalani rawat inap pada tahun 2014-2015. Pengambilan data dilakukan secara retrospektif, dengan mengambil data demografi pasien pada rekam medis dan penggunaan obat pada rekam medis dicocokan dengan lembar resep. Untuk memperoleh sampel, digunakan teknik purposive sampling. Kriteria inklusi meliputi pasien yang didiagnosa pneumonia serta mendapatkan terapi antibiotik. Kriteria eksklusi yang ditetapkan adalah pasien dengan penyakit penyerta infeksi lain.

\subsection{Alat dan Bahan}

Bahan yang digunakan dalam penelitian adalah rekam medik pasien rawat inapdan resep dari Instalasi Farmasi di RSUD Dr. Moewardi Surakarta periode 2014-2015.

Alat yang digunakan dalam penelitian adalah lembar pengumpulan data.

\subsection{Tempat dan Waktu}

Penelitian ini dilakukan di Instalasi Rekam Medik dan Instalasi Farmasi RSUD Dr. Moewardi Surakarta pada Januari-April tahun 2016

\subsection{Analisa Data}

Data yang diperoleh dikelompokan menjadi dua yaitu profil pasien dan data penggunaan obat. Data profil pasien dianalisis secara deskriptif dengan menghitung prosentase jenis kelamin, usia dan lama perawatan. Data pengobatan di rekam medis dicocokan dengan data resep untuk selanjutnya dihitung persentase penggunaan obatnya.

\section{Hasil dan Pembahasan}

\subsection{Distribusi pasien berdasarkan usia dan jenis kelamin}

Jumlah populasi pasien pneumonia pada tahun 2014 - 2015 adalah 496 pasien yang terdiri dari 31 pasien anak dan 281 pasien dewasa di tahun 2014, sedangkan tahun 2015 terdapat 39 pasien anak dan 145 pasien dewasa. Dari total populasi diperoleh subyek penelitian sebanyak83 pasien yang terdiri dari 25 pasien anak dan 58 pasien dewasa,. Dari hasil data tersebut dapat diketahui bahwa terjadi penurunan angka kejadin pneumonia pada tahun 2015.Gambaran karakteristik pasien berdasarkan usia dan jenis kelamin dapat dilihat pada tabel I.

Tabel I. Karakteristik pasien berdasarkan usia dan jenis kelamin

\begin{tabular}{ccccccc}
\hline \multirow{2}{*}{ Pasien } & \multirow{2}{*}{ Usia } & \multicolumn{2}{c}{ Jenis Kelamin } & \multirow{2}{*}{ Jumlah } & Persentase (\%) \\
& & Laki - laki & Perempuan & & \\
\hline \multirow{2}{*}{ Anak } & 0-5 tahun & 10 & 13 & 23 & 27,71 \\
& $6-12$ tahun & 1 & 1 & 2 & 2,41
\end{tabular}




\begin{tabular}{cccccc}
$13-16$ tahun & 1 & 0 & 1 & 1,20 \\
$17-25$ tahun & 1 & 1 & 2 & 2,41 \\
Dewasa & $26-35$ tahun & 1 & 4 & 5 & 6,02 \\
& $36-45$ tahun & 0 & 6 & 6 & 7,23 \\
& $46-55$ tahun & 8 & 6 & 14 & 16,87 \\
$56-65$ tahun & 14 & 6 & 20 & 24,09 \\
$>65$ tahun & 7 & 3 & 10 & 12,05 \\
Jumlah & 42 & 44 & 83 & 100 \\
\hline
\end{tabular}

Pada tabel I dapat diketahui bahwa angka kejadian pneumonia paling tinggi adalah usia kurang dari 5 tahun (balita). Hal ini sesuai dengan hasil Riset Kesehatan Dasar Tahun 2013 yang menunjukkan bahwa pneumonia tertinggi terjadi pada kelompok umur 1-4 tahun (Kemenkes, 2013). Anak dengan kelompok usia kurang dari 5 tahun rentan mengalami pneumonia berat dengan gejala batuk dan sukar bernapas. Sistem kekebalan tubuh anak pada usia tersebut juga sangat rentan sehingga mudah terinfeksi oleh penyakit yang ditularkan melalui udara (Misnadiarly, 2008).

Pada pasien dewasa, kejadian pneumonia paling tinggi pada kelompok usia $56-65$ tahun. Hal ini disebabkan karena pada usia lanjut terjadi perubahan anatomi fisiologi akibat proses penuaan memberi konsekuensi penting terhadap cadangan fungsional paru, kemampuan untuk mengatasi penurunan komplians paru dan peningkatan resistensi saluran napas terhadap infeksi dan penurunan daya tahan tubuh. Pasien geriatri lebih mudah terinfeksi pneumonia karena adanya gangguan reflek muntah, melemahnya imunitas, gangguan respon pengaturan suhu dan berbagai derajat kelainan kardiopulmoner (Rizqi dan Helmia, 2014).

Pada penelitian ini persentase anak perempuan lebih tinggi dari pada anak laki - laki. Hal ini kurang sesuai menurut Profil Kesehatan Indonesia Tahun 2011 menyebutkan bahwa penderita pneumonia sebagian besar berjenis kelamin laki-laki (Kemenkes, 2012). Pada dasarnya, pada pasien anak jenis kelamin bukan faktor risiko terjadinya pneumonia, akan tetapi lebih banyak dipengruhi oleh sistem kekebalan tubuh anak. Sistem kekebalan tubuh dapat dipengaruhi karena beberapa faktor, yaitu pemberian ASI eksklusif, status gizi, status imunisasi, polusi dari lingkungan, dan tempat tinggal yang terlalu padat (Anwar dan Dharmayanti, 2014).

Pada pasien dewasa persentase pasien laki - laki lebih tinggi daripada perempuan. Hal ini didukung oleh penelitian yang dilakukan oleh Adien (2015), menyatakan bahwa jumlah pasien pneumonia lebih didominasi oleh pasien laki-laki, dari 28 pasien pneumonia proporsi pasien laki-laki sebanyak 16 orang $(57,14 \%)$ dan pasien perempuan sebanyak 12 orang $(42,86 \%)$. Hal ini dapat dipengaruhi oleh faktor lingkungan yaitu sebagian besar perokok adalah laki - laki. Paparan asap rokok yang dialami terus menerus pada orang dewasa yang sehat dapat menambah resiko terkena penyakit paru-paru serta menjadi penyebab penyakit bronkitis, dan pneumonia (Elfidasari et al., 2013). 


\subsection{Distribusi pasien berdasarkan lama perawatan}

Lama perawatan merupakan salah satu faktor yang dapat digunakan untuk mengukur tingkat efektivitas penggunaan obat serta mengetahui gambaran rata-rata waktu terapi pasien pneumonia. Gambaran lama perawatan pasien dapat dilihat pada tabel II.

Tabel II. Distribusi pasien berdasarkan lama perawatan

\begin{tabular}{cccc}
\hline Lama perawatan & \multicolumn{2}{c}{ Pasien } & Jumlah \\
\hline 1 - 7 hari & 12 & Dewasa & \\
8 - 14 hari & 7 & 16 & 28 \\
15 - 21 hari & 3 & 34 & 41 \\
$>21$ hari & 3 & 4 & 7 \\
Jumlah & 25 & 4 & 7 \\
\hline
\end{tabular}

Berdasarkan tabel diketahui bahwa pasien anak paling banyak dirawat selama $1-7$ hari. Masa perawatan paling pendek adalah selama 3 hari dan paling lama adalah 36 hari. Pada pasien dewasa persentase lama perawatan paling tinggi yaitu $8-14$ hari, dengan perawatan paling pendek selama 4 hari dan paling lama selama 27 hari. Menurut Depkes RI (2005) antibiotik efektif digunakan untuk terapi selama kurang dari 10 hari sehingga kebanyakan pasien sudah diperbolehkan pulang sesudah mendapatkan perawatan di rumah sakit selama kurang dari 10 hari. Penelitian lain menyebutkan bahwa durasi efektif terapi antibiotik adalah 10-14 hari (Watkins dan Lemonovich, 2011). Hal ini sesuai dengan hasil penelitian iniyang menunjukan bahwa 69 pasien (total 83 pasien) dirawat dalam kurun waktu kurang dari 2 minggu.

\subsection{Pola penggunaan antibiotik}

Antibiotik yang digunakan pada pasien adalah terapi empirik karena tidak ditemukannya data pemeriksaan kultur untuk mengetahui penyebab pasti pneumonia. Pada penelitian ini penggunaan antibiotik dihitung dari antibiotik yang digunakan oleh semua pasien. Penggunaan antibiotik pada pasien pneumonia anak dapat dilihat pada tabel III.

Tabel III. Pola penggunaan antibiotik pada pasien anak

\begin{tabular}{cccccc}
\hline \multirow{2}{*}{$\begin{array}{c}\text { Penggunaan } \\
\text { Antibiotik }\end{array}$} & Jenis Antbiotik & \multicolumn{3}{c}{ Jumlah penggunaan pada tahun } \\
& & \multicolumn{2}{c}{2014} & \multicolumn{2}{c}{2015} \\
& Seftriakson & Jumlah & $\%$ & Jumlah & $\%$ \\
\hline \multirow{3}{*}{ Tunggal } & Gentamisin & 1 & 9,09 & 3 & 12 \\
& Meropenem & 0 & 0 & 1 & 4 \\
& Ampisilin & 1 & 9,09 & 1 & 4 \\
Kombinasi & Sefotaksim & 0 & 0 & 1 & 4 \\
& Ampisilin + Kloramfenikol & $\mathbf{0}$ & 0 & 1 & 4 \\
& & 3 & 27,27 & 3 & 12
\end{tabular}




\begin{tabular}{|c|c|c|c|c|}
\hline Ampisilin + Gentamisin & 2 & 18,18 & 8 & 32 \\
\hline Sefotaksim + Gentamisin & 1 & 9,09 & 4 & 16 \\
\hline Eritromisin + Metronidazol & 1 & 9,09 & $\mathbf{0}$ & $\mathbf{0}$ \\
\hline Seftriakson + Metronidazol & $\mathbf{0}$ & $\mathbf{0}$ & 2 & 8 \\
\hline Sefiksim + Metronidazol & $\mathbf{0}$ & $\mathbf{0}$ & $\mathbf{1}$ & 4 \\
\hline $\begin{array}{l}\text { Ampisilin + Sulbaktam + } \\
\text { Metronidazol + Gentamisin }\end{array}$ & 1 & 9,09 & $\mathbf{0}$ & $\mathbf{0}$ \\
\hline $\begin{array}{c}\text { Ampisilin + Sulbaktam + } \\
\text { Metronidazol + Kloramfenikol }\end{array}$ & 1 & 9,09 & $\mathbf{0}$ & $\mathbf{0}$ \\
\hline Total & 11 & 100 & 25 & 100 \\
\hline
\end{tabular}

Pada penelitian ini dapat diketahui bahwa antibiotik lebih banyak digunakan dalam bentuk kombinasi. Dari hasil tersebut dapat dibandingkan profil penggunaan antibiotik dari tahun 2014 ke tahun 2015. Pada tahun 2014 antibiotik tunggal yang paling banyak digunakan yaitu seftriakson dan meropenem, sedangkan pada tahun 2015 antibiotik yang paling banyak digunakan juga seftriakson. Hal ini dikarenakan seftriakson merupakan antibiotika golongan sefalosporin generasi ketiga. Antibiotik ini memiliki aktivitas yang sangat kuat untuk melawan bakteri gram negatif dan gram positif dan beberapa bakteri anaerob lain termasuk Streptococcus pneumoniae, Haemophilus influenzae, dan Pseudomonas (Jayesh, 2010). Menurut guideline IDSA tahun 2011, sefalosporin generasi ketiga (seftriakson dan sefotaksim) adalah antibiotik empirik yang direkomendasikan untuk pediatrik yang mendapatkan imunisasi tidak lengkap sedangkan ampicillin lebih disarankan untuk pediatrik yang mendapatkan imunisasi lengkap (Bradley et.al, 2011). Akan tetapi pada penelitian ini tidak diperoleh informasi tentang status imunisasi pasien sehingga tidak dapat dilakukan analisis kesesuaiannya.

Pada penggunaan antibiotik kombinasi pada pasien anak tahun 2014 yang paling banyak digunakan yaitu kombinasi ampisilin dengan kloramfenikol. Terapi kombinasi ampisilin dengan kloramfenikol karena kloramfenikol berkhasiat bakteriostatis terhadap hampir semua kuman gram positif dan sejumlah kuman gram negatif serta bekerja bakterisid terhadap Streptococcus pneumoniae, Haemophillus influenzae (Tjay dkk., 2007). Namun penelitian in vitro menunjukan kombinasi keduanya dapat menimbulkan interaksi obat secara farmakodinamik. Kloramfenikol bersifat antagonis terhadap efek ampisilin. Ampisilin akan memberikan efek optimal ketika bakteri dalam kondisi tumbuh dan membelah diri, sedangkan kloramfenikol menghambat sintesis protein sehingga aktivitasnya dihambat (Piscitelli dan Rodvold, 2007).

Pada tahun 2015 terdapat pergeseran penggunaan antibiotik kombinasi. Hal ini dapat dimungkinkan karena adanya resistensi kloramfenikol akan tetapi karena tidak terdapatnya hasil kultur sehingga tidak bisa diketahui penyebab pastinya. Pada tahun 2015 antibiotik kombinasi yang paling banyak digunakan yaitu kombinasi ampisilin dengan gentamisin. Hal ini disebabkan gentamisin yang dikombinasikan dengan penisilin atau vankomisin menghasilkan efek bakterisid yang kuat, yang sebagian disebabkan oleh peningkatan ambilan obat yang timbul karena penghambatan sintesis dinding sel. Penisilin mengubah struktur dinding sel sehingga memudahkan penetrasi gentamisin pada kuman (Katzung, 2004). 
Pola penggunaan antibiotik pada pasien dewasa berbeda dibandingkan dengan pasien anak. Pilihan antibiotik yang digunakan pada pasien dewasa lebih banyak dibandingkan pasien anak. Penggunaan antibiotik pada pasien pneumonia dewasa dapat dilihat pada tabel IV.

Tabel IV. Pola penggunaan antibiotik pada pasien dewasa

\begin{tabular}{|c|c|c|c|c|c|}
\hline \multirow{3}{*}{$\begin{array}{c}\text { Penggunaan } \\
\text { Antibiotik }\end{array}$} & \multirow{3}{*}{ Jenis Antbiotik } & \multicolumn{4}{|c|}{ Jumlah penggunaan pada tahun } \\
\hline & & \multicolumn{2}{|c|}{2014} & \multicolumn{2}{|c|}{2015} \\
\hline & & Jumlah & $\%$ & Jumlah & $\%$ \\
\hline \multirow{8}{*}{ Tunggal } & Seftriakson & 23 & 37,09 & 9 & 29,03 \\
\hline & Siprofloksasin & 4 & $\mathbf{6 , 4 5}$ & 3 & 9,68 \\
\hline & Levofloksasin & 6 & 9,68 & 2 & 6,45 \\
\hline & Azitromisin & 1 & 1,61 & 2 & 6,45 \\
\hline & Gentamisin & 1 & 1,61 & 1 & 3,22 \\
\hline & Meropenem & 1 & 1,61 & $\mathbf{0}$ & $\mathbf{0}$ \\
\hline & Eritromisin & $\mathbf{0}$ & $\mathbf{0}$ & 1 & 3,22 \\
\hline & Seftazidim & $\mathbf{0}$ & $\mathbf{0}$ & 2 & 6,45 \\
\hline \multirow{16}{*}{ Kombinasi } & Seftriakson + Azitromisin & 7 & 11,29 & 3 & 9,68 \\
\hline & Seftriakson + Gentamisin & 5 & 8,06 & 1 & 3,22 \\
\hline & Seftriakson + Siprofloksasin & 4 & 6,45 & $\mathbf{0}$ & $\mathbf{0}$ \\
\hline & Seftriakson + Kotrimoksazol & 3 & 4,84 & $\mathbf{0}$ & $\mathbf{0}$ \\
\hline & Seftriakson + Levofloksasin & 2 & 3,22 & 1 & 3,22 \\
\hline & Seftriakson + Metronidazol & $\mathbf{1}$ & 1,61 & 1 & 3,22 \\
\hline & Seftriakson + Streptomisin & 1 & 1,61 & $\mathbf{0}$ & $\mathbf{0}$ \\
\hline & Seftriakson + Eritromisin & 1 & 1,61 & $\mathbf{0}$ & $\mathbf{0}$ \\
\hline & Ampisilin + Gentamisin & $\mathbf{0}$ & $\mathbf{0}$ & 1 & 3,22 \\
\hline & $\begin{array}{c}\text { Seftriakson + Gentamisin }+ \\
\text { Metronidazol }\end{array}$ & 1 & 1,61 & $\mathbf{0}$ & $\mathbf{0}$ \\
\hline & $\begin{array}{c}\text { Seftriakson + Gentamisin }+ \\
\text { Azitromisin }\end{array}$ & 1 & 1,61 & $\mathbf{0}$ & $\mathbf{0}$ \\
\hline & $\begin{array}{c}\text { Seftriakson + Azitromisin }+ \\
\text { Levofloksasin }\end{array}$ & $\mathbf{0}$ & $\mathbf{0}$ & 1 & 3,22 \\
\hline & $\begin{array}{c}\text { Seftriakson + Metronidazol + } \\
\text { Gentamisin + Levofloksasin }\end{array}$ & $\mathbf{0}$ & $\mathbf{0}$ & 1 & 3,22 \\
\hline & $\begin{array}{c}\text { Metronidazol + Gentamisin + } \\
\text { Levofloksasin }\end{array}$ & $\mathbf{0}$ & $\mathbf{0}$ & 1 & 3,22 \\
\hline & Siprofloksasin + Azitromisin & $\mathbf{0}$ & $\mathbf{0}$ & 1 & 3,22 \\
\hline & Total & 62 & 100 & 31 & 100 \\
\hline
\end{tabular}

Pada tabel IV tersebut, dapat diketahui pada penggunaan antibiotik tunggal pada pasien dewasa tahun 2014 yang paling banyak digunakan yaitu seftriakson dan pada tahun 2015 antibiotik yang paling banyak digunakan juga seftriakson. Hal ini dikarenakan seftriakson merupakan antibiotik golongan sefalosporin generasi ketiga yang digunakan sebagai lini pertama untuk mengobati sejumlah besar infeksi parah yang diakibatkan oleh organisme - organisme yang resisten 
terhadap obat lain (Katzung, 2004). Seftriakson paling banyak digunakan karena seftriakson merupakan antibiotika golongan sefalosporin generasi ketiga. Antibiotik ini memiliki aktivitas yang sangat kuat untuk melawan bakteri gram negatif dan gram positif dan beberapa bakteri anaerob lain termasuk Streptococcus pneumoniae, Haemophilus influenzae, dan Pseudomonas (Jayesh, 2010).

Pada penggunaan antibiotik kombinasi pada pasien dewasa tahun 2014 dan 2015yang paling banyak digunakan yaitu seftriakson dan azitromisin. Hal ini telah sesuai dengan rekomendasi dari beberapa guideline yang menyatakan bahwa terapi pasien rawat inap non ICU dewasa dapat menggunakan antibiotik beta laktam seperti seftriakson dikombinasikan dengan makrolida seperti azitromisin (Watkins dan Lemonovich, 2011).

Selain mendapatkan obat selama rawat inap, pasien juga diresepkan obat untuk terapi lanjutan rawat jalan. Penggantian antibiotik dimungkinkan untuk terapi rawat jalan mengingat kondisi pasien yang sudah membaik dan untuk kemudahan pasien menggunakan obat. Gambaran antibiotik untuk terapi lanjutan dapat dilihat pada tabel V.

Tabel V. Antibiotik sebagai obat pulang atau terapi lanjutan

\begin{tabular}{|c|c|c|c|c|c|}
\hline \multirow{3}{*}{ Pasien } & \multirow{3}{*}{ Jenis Antibiotik } & \multicolumn{4}{|c|}{ Jumlah penggunaan pada tahun } \\
\hline & & \multicolumn{2}{|c|}{2014} & \multicolumn{2}{|c|}{2015} \\
\hline & & Jumlah & $\%$ & Jumlah & $\%$ \\
\hline \multirow{3}{*}{ Anak } & Sefiksim & 5 & 83,33 & 10 & 76,92 \\
\hline & Kloramfenikol & 1 & 16,67 & $\mathbf{0}$ & $\mathbf{0}$ \\
\hline & Amoksisilin & $\mathbf{0}$ & $\mathbf{0}$ & 3 & 23,08 \\
\hline \multirow{5}{*}{ Dewasa } & Total & 6 & 100 & 13 & 100 \\
\hline & Sefiksim & 14 & 73,68 & 2 & 50 \\
\hline & Amoksisilin & 5 & 26,32 & 1 & 25 \\
\hline & Sefiksim + Levofloksasin & $\mathbf{0}$ & $\mathbf{0}$ & 1 & 25 \\
\hline & Total & 19 & 100 & 4 & 100 \\
\hline
\end{tabular}

Pada tabel V, dapat diketahui bahwa antibiotik untuk terapi lanjutan yang paling banyak digunakan pada pasien anak maupun dewasa di tahun 2014 dan 2015 yaitu antibiotik sefiksim. Hal ini dikarenakan rute pemberian sefiksim adalah peroral. Pasien yang telah membaik memang disarankan untuk mengganti antibiotik intravena menjadi per oral Antibiotik oral sudah dapat diberikan setelah 3 hari penggunaan antibiotik intravena. Penggantian antibiotik oral lebih awal terbukti efektif dan dapat ditoleransi dengan baik oleh pasien (Watkins dan Lemonovich, 2011). Selain itu, antibiotik oral diberikan untuk obat pulang karena dalam pemakaiannya tidak perlu memiliki keahlian khusus.

\section{Kesimpulan}

Pasien pneumonia pada tahun 2014 - 2015 didominasi oleh pasien anak usia 0 - 5 tahun yaitu $27,71 \%$ dan berjenis kelamin perempuan dengan rata - rata lama perawatan 11 hari. Antibiotik 
tunggal yang digunakan oleh sebagian besar pasien anak dan dewasa pada tahun 2014-2015 adalah seftriakson $(21,09 \%$ dan 66,12\%). Antibiotik kombinasi pada tahun 2014-2015 pasien anak sebagian besar adalah ampicillin dan gentamisin $(39,27 \%)$ sedangkan pada pasien dewasa seftriakson dan azitromisin $(26,97 \%)$.

\section{Conflicts of Interest}

The authors declare no conflict of interest

\section{Daftar Pustaka}

Andien, M. K., 2015, Evaluasi Penggunaan Antibiotik pada Pasien Pneumonia di RSUD Sukoharjo Tahun 2014, Skripsi, Fakultas Farmasi Universitas Muhammadiyah Surakarta, Surakarta

Anwar A, dan Dharwayanti I, Pneumonia pada Anak Balita di Indonesia, Jurnal Kesehatan Masyarakat Nasional, 2014;8(8): 359-365

.Depkes RI, 2005, Pharmaceutical Care Untuk Infeksi Saluran Pernafasan, Departemen Kesehatan Republik Indonesia, Jakarta.

Elfidasari, D., Noriko, N., Mirasaraswati, A., Feroza, A., dan Canadianti, S.F., 2013, Deteksi Bakteri Klebsiella pneumonia pada Beberapa jenis Rokok Konsumsi Masyarakat, Jurnal Al-Azhar Indonesia Seri Sains DanTeknologi, 2: (1), 41-47.

File, T.M., Bartlet J.G., Thomer, A.r. Treatment of community-acquired pneumonia in adults who require hospitalization, $U p$ to Date Wolters Kluwer, tersedia di http://www.uptodate.com/contents/treatment-of-community-acquired-pneumonia-in-adults-whorequire-hospitalizationdiakses tanggal 28 Agustus 2016

Jayesh J. M, Harshad V. G, Shailesh K. B, Urvesh D. P and Aswin M. T., 2010, Pharmacokinetics of Ceftriaxone in Calves, Veterinarski arhiv, 80(1): 1-9.

Kaparang, Pingkan C., Heedy T., Paulina V.Y.Y., 2014, Evaluasi Kerasioanal Antibiotika Pada Pengobatan Pneumonia Anak Di Instalasi Rawat Inap RSUP Prof. Dr. R. D. Kondou Monado Periode Januari - Desember 2013, Jurnal IlmiahFarmasi, Vol. 3 No. 3, Fakultas Matematika Ilmu Pengetahuan Alam, Universitas Sam Ratulangi, Manado.

Katzung, B.G., 2004, Farmakologi Dasar dan Klinik, Buku III, Edisi VIII, Salemba Medika, Jakarta.

Kemenkes, 2012, Profil Kesehatan Indonesia Tahun 2011, Kementerian Kesehatan Republik Indonesia, Jakarta.

Kemenkes , 2013, Riset Kesehatan Dasar 2013, Badan Penelitian dan Pengembangan Kesehatan Kementerian Kesehatan Republik Indonesia, Jakarta.

Khairudin, 2009, Kajian Rasionalitas Penggunaan Antibiotik Pada Pasien Pneumonia Yang Dirawat Pada Bangsal Penyakit Dalam Di RSUP Dr. Kariadi Semarang Tahun 2008, Karya Tulis Ilmiah, Fakultas Kedokteran, Universitas Diponegoro, Semarang

Misnadiarly, 2008, Penyakit Infeksi Napas Pneumonia pada Anak, Orang Dewasa, Usia Lanjut, Pneumonia Atipik \& Pneumonia Atypik Mycobacterium, Pustaka Obor Populer, Jakarta.

Piscitelli dan Rodvold, 2007, Drug Interactions in Infectious Diseases $2^{\text {nd }}$ Edition, Springer Science \& Business Media, New York

Rizqi M.H., dan Helmia Hasan, Tinjauan Imunologi Pneumonia pada Pasien Geriatri, $\underline{C D K-212}$, 2014;41(1): 14-18. 